\title{
An Assessment of Learning Styles among Undergraduate Medical Students at King Saud bin Abdulaziz University (KSAUHS), King Saud University (KSU) and Imam Mohammad Ibn Saud Islamic University (IMSIU)
}

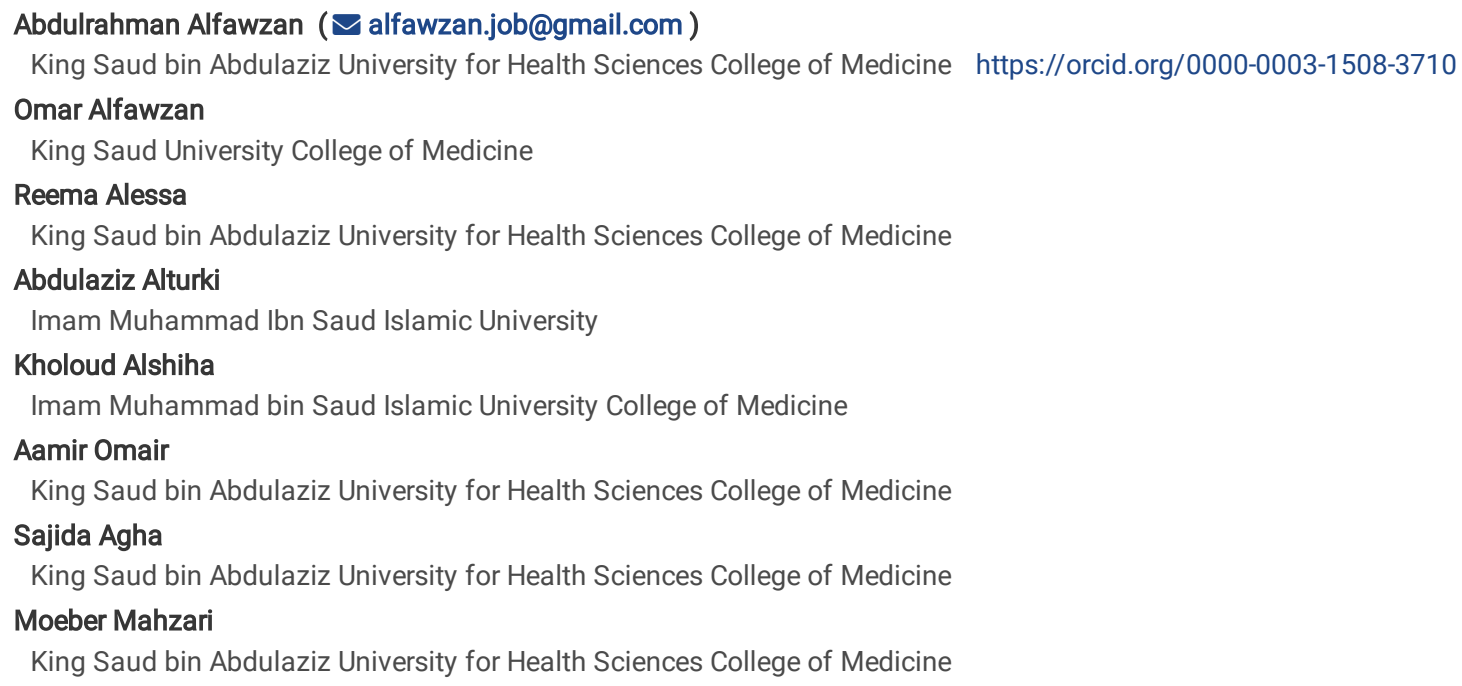




\section{Abstract \\ Background}

Learning style refers to how students prefer to receive, process and recall information. Research in academia suggests that different teaching strategies could have an impact on learning style. The study aims to identify the learning style of medical students in three different universities in Riyadh, Saudi Arabia.

\section{Method:}

This cross-sectional study examined the learning preferences among medical students in basic science years in three universities in Riyadh, Saudi Arabia. By using consecutive sampling, we collected 316 responses. The questionnaire consisted of sociodemographic data and Index of Learning Style (ILS) instrument. Descriptive data were analyzed using chi-square by SPSS.

\section{Results}

Of the 316 participants, the male to female ratio was 1:1. Gender was associated with significant difference in the visual/verbal dimension $(P=0.034)$. Irrespective of college, most of the participants are primarily balanced in active/reflective (mean = 0.7), with slight shift toward sensing (mean $=-3.2)$, visual (mean =-3.2), and sequential (-1.7). Significant differences between colleges were found in sensing/intuitive $(P=0.005)$ and sequential $/ g l o b a l(P=0.012)$ dimensions. There was no significant association between academic years with learning style in the three universities.

\section{Conclusion}

The study showed that age and GPA had no association with students' learning styles, while gender was significantly correlated with the visual/verbal dimension. Most of the participants can learn alone, and/or in groups, and prefer visual illustrations supported by hands-on teaching in a stepwise process. It has also been shown that students in a single university tend to develop the same learning styles as they advance through the years.

\section{Introduction:}

Recently, medical education has shifted from traditional, teacher-focused learning into a student-centered approach. Knowledge of the favorable student learning style can enhance the learning process as well as student performance, and provide a better understanding of the learning difficulties that learners may encounter.(1) Learning style, also known as "learning modalities," "learning strategies," "approaches to learning," refers to how students prefer to receive, process, and recall the information. $(2,3)$ Learning style questionnaires are an essential tool to identify the pros and cons of the applicated learning strategy and create better programs that meet the student's needs.(4) Generally, student learning can be enhanced when the medical curriculum includes a variety of teaching methods suitable for different learning styles.(3) It can be argued, however, that the influence of the medical curriculum type on students' learning style preferences is not well studied.

The student-centered approach focuses on delivering information in various ways to different students. It is crucial to use effective tools that help identify specific types of learning styles. Many instruments have been invented to determine students' learning styles to make the most of their abilities. Visual, Aural, Read/Write, and Kinesthetic (VARK) is a case in point, developed by Fleming.(5) VARK divides learners into Visual, Auditory, Write/Read, and Kinesthetic. While VARK is easy to use and provides reliable results, it depends mainly on the sensory modality to obtain the information rather than the process of how students comprehend new information. On the other hand, Kolb's learning style inventory (K-LSI) is a widely used tool for the identification of the different learning styles.(6) K-LSI divides learners into four main learning styles: divergent, assimilator, convergent, and accommodator, based on experiential learning theory (ELT) by David Kolb.(6) Another learning style instrument is the Index of Learning Styles (ILS), invented by Richard M. Felder and Linda K. Silverman.(7-10) ILS has been recently validated for research in the medical field(11-13), and several studies utilized ILS due to its simplicity and accessibility.(14-16) It has four dimensions: active/reflective, sensing/intuitive, visual/verbal and sequential/global. Every dimension has two categories, and learners could be strong in one category or balanced.

In Saudi Arabia, several studies have been conducted to determine the learning style preferences of medical students.(17-22) These studies used a variety of tools to determine the learning styles of the participants; $(5-7,23)$ however, none compared the different learning styles of medical students in colleges.

Due to the limitations of global and local research on the impact of different learning strategies on the development of learning styles, this study aims to identify the learning styles of medical students in three universities, namely King Saud bin Abdulaziz University for Health Sciences (KSAUHS), King Saud University (KSU) and Imam Mohammad Ibn Saud Islamic University (IMSIU). Each university follows a distinct learning strategy. In KSAUHS, the main principle is self-directed learning represented by three Problem-Based Learning (PBL) sessions per week during the pre-clinical phase where students are innovative and active throughout the learning process. KSU adopts an approach to teaching in which lectures are the primary focus. Finally, IMSIU uses a hybrid approach to teaching strategies, focusing on lectures, and student-centered learning such as PBL. This study compares the different learning styles adopted in the three universities.

\section{Method:}


This cross-sectional study was conducted on pre-clinical year students in three medical colleges at King Saud bin Abdulaziz University for Health Sciences (KSAU-HS), King Saud University (KSU), and Al-Imam Mohammad Ibn Saud Islamic University (IMSIU) in Riyadh, Saudi Arabia. Only colleges that share a similar PBL-based curriculum were included. Students in the preparatory year and clinical year programs, interns, and incomplete ILS responses were excluded. Prior to data collection, an IRB approval was obtained from King Abdullah International Medical Research Center (KAIMRC). Informed consent was secured before participants' enrollment in the study.

By using consecutive sampling techniques, we collected data from 334 pre-clinical year medical students in three universities. Out of 334 students, we excluded 18 questionnaires with missing data. We used a self-administered Index of Learning Styles (ILS) questionnaire to assess the different learning styles, developed by Richard M. Felder and Barbara A. The Index of Learning Styles (ILS) was distributed among students along with sociodemographic data, including age, gender, university, basic medical year, and GPA. The ILS has four dimensions: active/reflective, sensing/intuitive, visual/verbal, and sequential/global. Each dimension consists of 11 statements (a total of 44 statements) and has 2 options: (A) which scores for active, sensing, visual, and sequential, and (B) which corresponds to other categories in the dimensions. The highest score in A or B determines the participant's inclination towards that learning style. The learner's styles in each dimension are represented as follows:

1- Knowledge procession:

\begin{tabular}{|c|c|c|}
\hline $\begin{array}{l}\text { B. active: works by discussing, } \\
\text { applying, and explaining to } \\
\text { others. }\end{array}$ & versus & $\begin{array}{l}\text { A. reflective: works by thinking } \\
\text { through before conducting } \\
\text { anything. }\end{array}$ \\
\hline
\end{tabular}

2- Knowledge perception:

B. sensing: perceives facts and solve problems by making practical plans.

A. intuitive: perceives ideas and theories.

3- Knowledge input:

A. visual: gains knowledge through pictures, graphs, reading. versus

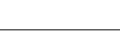

reading.

4- Knowledge comprehension:

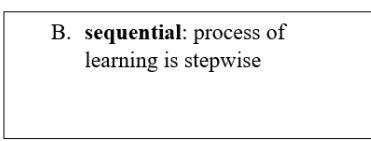

B. verbal: gains knowledge through speaking and listening.

We utilized Google forms for data entry and SPSS version 22 for data analysis. We presented categorical data as percentages and frequencies and used chi squared test to compare students' learning styles. For numerical data, we calculated mean and standard deviation. A P value less than 0.05 was considered statistically significant.

\section{Results:}

A total of 316 responses were found eligible. The male to female ratio was 1:1. Most of the students were in the 20-year-old age group. The most received responses were from IMSIU (36\%), as $40 \%$ of the participants have a 5-4.75 GPA. The complete demographic information is illustrated in Table 1. Irrespective of college, most of the participants are primarily balanced in active/reflective (mean $=0.7$ ), with slight shift toward sensing (mean $=-3.2)$, visual (mean $=-3.2$ ), and sequential (-1.7). 
Table 1

Participants' characteristics

\begin{tabular}{|c|c|c|}
\hline & Frequency & Percentage \\
\hline \multicolumn{3}{|l|}{ Gender } \\
\hline Male & 158 & $50 \%$ \\
\hline Female & 158 & $50 \%$ \\
\hline \multicolumn{3}{|l|}{ Age } \\
\hline $18-19$ Years & 71 & $22.6 \%$ \\
\hline 20 Years & 103 & $23.8 \%$ \\
\hline 21 Years & 90 & $28.7 \%$ \\
\hline $22+$ Years & 50 & $15.9 \%$ \\
\hline \multicolumn{3}{|l|}{ University } \\
\hline KSAUHS & 90 & $28.4 \%$ \\
\hline KSU & 113 & $35.6 \%$ \\
\hline IMSIU & 114 & $36.0 \%$ \\
\hline \multicolumn{3}{|l|}{ Year } \\
\hline First year & 134 & $42.3 \%$ \\
\hline Second year & 156 & $49.2 \%$ \\
\hline Third year & 27 & $8.5 \%$ \\
\hline \multicolumn{3}{|l|}{ GPA } \\
\hline $5-4.75$ & 117 & $39.9 \%$ \\
\hline $4.74-4.50$ & 98 & $33.5 \%$ \\
\hline $4.49-4.25$ & 77 & $26.2 \%$ \\
\hline \multicolumn{3}{|c|}{ Learning Style } \\
\hline \multicolumn{3}{|c|}{ Active/Reflective } \\
\hline active & 38 & $12 \%$ \\
\hline Balanced & 213 & $67.2 \%$ \\
\hline reflective & 66 & $20.8 \%$ \\
\hline \multicolumn{3}{|c|}{ Sensing/Intuitive } \\
\hline Sensing & 151 & $47.6 \%$ \\
\hline balanced & 138 & $43.5 \%$ \\
\hline Intuitive & 28 & $8.8 \%$ \\
\hline \multicolumn{3}{|l|}{ Visual/Verbal } \\
\hline Visual & 136 & $42.9 \%$ \\
\hline Balanced & 162 & $51.1 \%$ \\
\hline Verbal & 19 & $6 \%$ \\
\hline \multicolumn{3}{|c|}{ Sequential/Global } \\
\hline Sequential & 81 & $25.6 \%$ \\
\hline Balanced & 218 & $68.8 \%$ \\
\hline global & 18 & $5.7 \%$ \\
\hline
\end{tabular}

Table 2 represents the association of participants' learning styles with gender, age, and GPA. A significant difference between males and females was shown in the visual/verbal dimension $(P=0.034)$. Females $(9.5 \%)$ were slightly more verbal than males $(2.5 \%)$. Other demographic characteristics showed no association with learning styles. 
Table 2

Association of participants' learning styles according to participants' characteristics

\begin{tabular}{|c|c|c|c|c|c|c|c|c|c|c|c|c|}
\hline & \multicolumn{3}{|c|}{ Active/Reflective } & \multicolumn{3}{|c|}{ Sensing/Intuitive } & \multicolumn{3}{|c|}{ Visual/Verbal } & \multicolumn{3}{|c|}{ Sequential/Global } \\
\hline & Active & Balanced & Reflective & Sensing & Balanced & Intuitive & Visual & Balanced & Verbal & Sequential & Balanced & Globa \\
\hline \multicolumn{13}{|l|}{ Gender } \\
\hline Male & $\begin{array}{l}18 \\
(11.4)\end{array}$ & $\begin{array}{l}103 \\
(65.2)\end{array}$ & $37(23.4)$ & $79(50)$ & $66(41.8)$ & $13(8.2)$ & $\begin{array}{l}70 \\
(44.3)\end{array}$ & $84(53.2)$ & $4(2.5)$ & $40(25.3)$ & $\begin{array}{l}112 \\
(70.9)\end{array}$ & $6(3.8)$ \\
\hline Female & $\begin{array}{l}20 \\
(12.7)\end{array}$ & $109(69)$ & $29(18.4)$ & $\begin{array}{l}72 \\
(45.6)\end{array}$ & $71(44.9)$ & $15(9.5)$ & $\begin{array}{l}66 \\
(41.8)\end{array}$ & 77 (48.7) & $\begin{array}{l}15 \\
(9.5)\end{array}$ & $41(25.9)$ & $\begin{array}{l}105 \\
(66.5)\end{array}$ & $\begin{array}{l}12 \\
(7.6)\end{array}$ \\
\hline P-value & 0.537 & & & 0.723 & & & 0.034 & & & 0.327 & & \\
\hline \multicolumn{13}{|l|}{ Age: } \\
\hline $\begin{array}{l}18-19 \\
\text { Years }\end{array}$ & $9(12.7)$ & $43(60.6)$ & $19(26.8)$ & $\begin{array}{l}34 \\
(47.9)\end{array}$ & $32(45.1)$ & $5(7)$ & $\begin{array}{l}34 \\
(47.9)\end{array}$ & $33(46.5)$ & $4(5.6)$ & $14(19.7)$ & $51(71.8)$ & $6(8.5)$ \\
\hline 20 Years & $\begin{array}{l}14 \\
(13.6)\end{array}$ & $69(67)$ & 20 (19.4) & $\begin{array}{l}44 \\
(42.7)\end{array}$ & $51(49.5)$ & $8(7.8)$ & $\begin{array}{l}42 \\
(40.8)\end{array}$ & $54(52.4)$ & $7(6.8)$ & $30(29.1)$ & $68(66)$ & $5(4.9)$ \\
\hline 21 Years & $\begin{array}{l}10 \\
(11.1)\end{array}$ & $61(67.8)$ & $19(21.1)$ & $\begin{array}{l}48 \\
(53.3)\end{array}$ & $33(36.7)$ & $9(10)$ & $\begin{array}{l}37 \\
(41.1)\end{array}$ & 48 (53.3) & $5(5.6)$ & $27(30)$ & $60(66.7)$ & $3(3.3)$ \\
\hline $22+$ Years & $5(10)$ & $37(74)$ & $8(16)$ & $24(48)$ & $20(40)$ & $6(12)$ & $22(44)$ & $26(52)$ & $2(4)$ & $10(20)$ & $37(74)$ & $3(6)$ \\
\hline P-value & 0.794 & & & 0.646 & & & 0.96 & & & 0.517 & & \\
\hline \multicolumn{13}{|l|}{ GPA: } \\
\hline $5-4.75$ & $9(7.7)$ & $80(68.4)$ & $28(23.9)$ & $\begin{array}{l}53 \\
(45.3)\end{array}$ & $53(45.3)$ & $11(9.4)$ & $\begin{array}{l}49 \\
(41.9)\end{array}$ & $57(48.7)$ & $\begin{array}{l}11 \\
(9.4)\end{array}$ & $27(23.1)$ & $81(69.2)$ & $9(7.7)$ \\
\hline $4.74-4.25$ & $\begin{array}{l}17 \\
(17.3)\end{array}$ & $61(62.2)$ & $20(20.4)$ & $49(50)$ & $40(40.8)$ & $9(9.2)$ & $\begin{array}{l}40 \\
(40.8)\end{array}$ & $53(54.1)$ & $5(5.1)$ & $25(25.5)$ & $69(70.4)$ & $4(4.1)$ \\
\hline$<4.25$ & 10 (13) & 55 (71.4) & $12(15.6)$ & $\begin{array}{l}35 \\
(45.5)\end{array}$ & $36(46.8)$ & $6(7.8)$ & $\begin{array}{l}37 \\
(48.1)\end{array}$ & $39(50.6)$ & $1(1.3)$ & $24(31.2)$ & $51(66.2)$ & $2(2.6)$ \\
\hline P-value & 0.182 & & & 0.932 & & & 0.18 & & & 0.411 & & \\
\hline
\end{tabular}

The comparative assessment of medical students' learning styles in the three universities revealed similar patterns among students, in particular the active/reflective and visual/verbal dimensions. Negative mean indicates preference of learning toward active, sensing, sequential, and visual, while positive mean indicates preference toward reflective, intuitive, global, and verbal. The mean of active/reflective is $0.9,0.6$, and 0.6 for KSAU-HS, KSU, and IMSIU, respectively. The equal mean is shown in visual/verbal category $-3.6,-3$, and -3.2 for $\mathrm{KSAU}-\mathrm{HS}, \mathrm{KSU}$, and IMSIU, while the mean (-2.5) is slightly less sensing in KSU than KSAU-HS (-3.3) and IMSIU (-3.7) participants. Also, KSU students have a more balanced mean (-1) in sequential/global dimension compared with KSAU-HS (-1.7) and IMSIU (-2.2) students. In sensing/intuitive and sequential/global categories, there was a marked difference in the median, minimum, and maximum results, as shown in graph 1 . The median (-3) of IMSIU was shifted to sequential in comparison to KSAU-HS and KSU, while KSU participants had narrower quartiles than KSAU-HS and IMSIU. KSU median was less sensing (-3) in comparison to KSAU-HS (-4) and IMSIU (-5).

The comparative assessment also showed no significant association in the active/reflective and visual/verbal dimensions. However, a significant association between universities in sensing/intuitive $(P=0.005)$ and sequential/global $(P=0.012)$ categories was reported. In the active/reflective dimension, two quarters of each college are balanced. KSAU-HS (50\%) and IMSIU (57.9\%) participants shifted toward sensing while most KSU participants were balanced. In visual/verbal and sequential/global categories, most of the participants were balanced (Table 3).

Table 3

Association of participants' learning styles according to participants' university

\begin{tabular}{|c|c|c|c|c|c|c|c|c|c|c|c|c|c|}
\hline & \multicolumn{3}{|c|}{ Active/Reflective } & \multicolumn{3}{|c|}{ Sensing/Intuitive } & \multicolumn{3}{|c|}{ Visual/Verbal } & \multicolumn{4}{|c|}{ Sequential/Global } \\
\hline & Active & Balanced & Reflective & Sensing & Balanced & Intuitive & Visual & Balanced & Verbal & Sequential & Balanced & Global & \\
\hline KSAUHS & $\begin{array}{l}7 \\
(7.8)\end{array}$ & $68(75.6)$ & $15(16.7)$ & $45(50)$ & $38(42.2)$ & $7(7.8)$ & $\begin{array}{l}40 \\
(44.4)\end{array}$ & $45(50)$ & $\begin{array}{l}5 \\
(5.6)\end{array}$ & $24(26.7)$ & $63(70)$ & $3(3.3)$ & 90 \\
\hline KSU & $\begin{array}{l}15 \\
(13.3)\end{array}$ & $73(64.6)$ & $25(22.1)$ & $\begin{array}{l}40 \\
(35.4)\end{array}$ & $64(56.6)$ & $9(8)$ & $\begin{array}{l}48 \\
(42.5)\end{array}$ & $57(50.4)$ & $\begin{array}{l}8 \\
(7.1)\end{array}$ & $20(17.7)$ & 81 (71.7) & $\begin{array}{l}12 \\
(10.6)\end{array}$ & 113 \\
\hline IMSIU & $\begin{array}{l}16 \\
(14)\end{array}$ & $72(63.2)$ & $26(22.8)$ & $\begin{array}{l}66 \\
(57.9)\end{array}$ & $36(31.6)$ & $\begin{array}{l}12 \\
(10.5)\end{array}$ & $\begin{array}{l}48 \\
(42.1)\end{array}$ & $60(52.6)$ & $\begin{array}{l}6 \\
(5.3)\end{array}$ & $37(32.5)$ & $74(64.9)$ & $3(2.6)$ & 114 \\
\hline P-value & 0.371 & & & 0.005 & & & 0.973 & & & 0.012 & & & \\
\hline
\end{tabular}

KSAUHS: King Saud bin Abdulaziz University for Health Sciences. KSU: King Saud University. IMSIU: Imam Mohammad ibn Saud Islamic University. 
There was no significant association between academic years in each university, but it should be noted that a slight insignificance $(P=0.064)$ was found in the visual/verbal category in IMSIU. The visual/verbal domain in IMSIU showed that as students progress towards last year of basic science, they become more balanced $(74.1 \%)$ in comparison with first (43.5\%) and second (48.8) years, respectively. (See Table 4)

Table 4

Association of participants' learning styles according to participants' academic year

\begin{tabular}{|c|c|c|c|c|c|c|c|c|c|c|c|c|}
\hline & \multicolumn{3}{|c|}{ Active/Reflective } & \multicolumn{3}{|c|}{ Sensing/Intuitive } & \multicolumn{3}{|c|}{ Visual/Verbal } & \multicolumn{3}{|c|}{ Sequential/Global } \\
\hline & Active & Balanced & Reflective & Sensing & Balanced & Intuitive & Visual & Balanced & Verbal & Sequential & Balanced & Global \\
\hline \multicolumn{13}{|l|}{ KSAUHS } \\
\hline $\begin{array}{l}\text { First } \\
\text { year }\end{array}$ & $\begin{array}{l}2 \\
(7.4)\end{array}$ & $21(77.8)$ & $4(14.8)$ & $\begin{array}{l}14 \\
(51.9)\end{array}$ & $11(40.7)$ & $2(7.4)$ & $\begin{array}{l}12 \\
(44.4)\end{array}$ & $13(48.1)$ & $\begin{array}{l}2 \\
(7.4)\end{array}$ & $9(33.3)$ & $17(63)$ & $1(3.7)$ \\
\hline $\begin{array}{l}\text { Second } \\
\text { Year }\end{array}$ & $\begin{array}{l}5 \\
(7.9)\end{array}$ & $47(74.6)$ & $11(17.5)$ & $\begin{array}{l}31 \\
(49.2)\end{array}$ & $27(42.9)$ & $5(7.9)$ & $\begin{array}{l}28 \\
(44.4)\end{array}$ & $32(50.8)$ & $\begin{array}{l}3 \\
(4.8)\end{array}$ & $15(23.8)$ & $46(73)$ & $2(3.2)$ \\
\hline P-value & 0.943 & & & 0.974 & & & 0.876 & & & 0.628 & & \\
\hline \multicolumn{13}{|l|}{ KSU } \\
\hline $\begin{array}{l}\text { First } \\
\text { year }\end{array}$ & $6(9.8)$ & $42(68.9)$ & $13(21.3)$ & $\begin{array}{l}19 \\
(31.1)\end{array}$ & $36(59)$ & $6(9.8)$ & $\begin{array}{l}29 \\
(45.9)\end{array}$ & $29(47.5)$ & $\begin{array}{l}4 \\
(6.6)\end{array}$ & $12(19.7)$ & $41(67.2)$ & $\begin{array}{l}8 \\
(13.1)\end{array}$ \\
\hline $\begin{array}{l}\text { Second } \\
\text { Year }\end{array}$ & $\begin{array}{l}9 \\
(17.3)\end{array}$ & $31(59.6)$ & $12(23.1)$ & $\begin{array}{l}21 \\
(40.4)\end{array}$ & $28(53.8)$ & $3(5.8)$ & $\begin{array}{l}20 \\
(38.5)\end{array}$ & $18(53.8)$ & $\begin{array}{l}4 \\
(7.7)\end{array}$ & $8(15.4)$ & $40(76.9)$ & $\begin{array}{l}4 \\
(7.7)\end{array}$ \\
\hline P-value & 0.451 & & & 0.499 & & & 0.727 & & & 0.487 & & \\
\hline \multicolumn{13}{|l|}{ IMSUI } \\
\hline $\begin{array}{l}\text { First } \\
\text { year }\end{array}$ & $3(6.5)$ & $32(69.6)$ & $11(23.9)$ & $\begin{array}{l}27 \\
(58.7)\end{array}$ & $16(34.8)$ & $3(6.5)$ & $\begin{array}{l}23 \\
(50)\end{array}$ & $20(43.5)$ & $\begin{array}{l}3 \\
(6.5)\end{array}$ & $16(34.8)$ & $29(63)$ & $\begin{array}{l}1 \\
(2.2)\end{array}$ \\
\hline $\begin{array}{l}\text { Second } \\
\text { Year }\end{array}$ & $\begin{array}{l}20 \\
(24.4)\end{array}$ & $22(53.7)$ & $9(22)$ & $25(61)$ & $11(26.8)$ & $5(12.2)$ & $\begin{array}{l}20 \\
(48.8)\end{array}$ & $20(48.8)$ & $\begin{array}{l}1 \\
(2.4)\end{array}$ & $12(29.3)$ & $29(70.7)$ & $0(0)$ \\
\hline $\begin{array}{l}\text { Third } \\
\text { Year }\end{array}$ & $\begin{array}{l}3 \\
(11.1)\end{array}$ & $18(66.7)$ & $6(22.2)$ & $\begin{array}{l}14 \\
(51.9)\end{array}$ & $9(33.3)$ & $4(14.8)$ & $\begin{array}{l}5 \\
(18.5)\end{array}$ & $20(74.1)$ & $\begin{array}{l}2 \\
(7.4)\end{array}$ & $9(33.3)$ & $16(59.3)$ & $\begin{array}{l}2 \\
(7.4)\end{array}$ \\
\hline P-value & 0.19 & & & 0.737 & & & 0.064 & & & 0.401 & & \\
\hline
\end{tabular}

\section{Discussion:}

One of the most effective ways to achieve quality education in student-centered learning is to identify and adapt the learning styles to the education system, which can ultimately improve students' learning performance. To this end, we identified the learning styles of basic science year medical students and found discrepancies in the learning styles between the three universities.

Irrespective of college, most of the participants are primarily balanced in active/reflective with a slight shift toward sensing, visual, and sequential, which means they can learn effectively from active discussions in groups, or independently, and think the situation through before acting. Also, they slightly prefer facts and use visual materials such as pictures, graphics, and books for stepwise learning. A study conducted on undergraduate health education students (n = 505) showed similar results.(24) Out of 505 participants, 72 Pre-medicine students are more likely to be reflective (56.9\%), sensing (83.4\%), visual (76.4\%), and sequential (70.8).(24) First-year medical students' learning preferences were sensing (54.9\%), active (50.9\%), sequential (60.5\%), and visual (80.8\%) with medians equal $-0.9,0.7,-0.8$, and -5.1 , respectively.(15) Two studies revealed that participants were mainly more visual $(76.7 \%$ and $90 \%)$ and sensing $(79.3 \%$ and $64 \%) \cdot(25,26)$

The current study reported a significant difference between colleges and information perception $\mathrm{P}=0.005$ (sensing/intuitive dimension). About $90 \%$ of the participants shifted toward sensing and balanced. Only KSU had more balanced participants than sensing. The higher number of sensing learners in IMSIU could be attributed to the intensive teaching sessions, as sensing learners prefer to learn facts, solve problems, and perform hands-on tasks and dislike being tested on materials that have not been fully explained during the sessions. On the other hand, KSAUHS deliver less lectures, and provide more PBL's and casediscussions. The sessions conducted KSAUHS offer general information about the subject and depend mostly on self-learning. For example, case-discussions and PBL are introduced to encourage students to become more active and articulate when sharing their thoughts and ideas with colleagues, while the tutor, i.e. supervisor, corrects mistakes and directs the session with limited interference. Generally, KSAUHS and IMSIU has PBL case every week. KSU curriculum has lower number of PBL in comparison for the other universities. For example, foundation block includes 4 PBL cases in 13 weeks duration while musculoskeletal block include 3 in 7 week duration.

It is usually assumed that medical students are more sequential (learning stepwise) than global (gaining knowledge by covering a lot of ground). Medical students learn step-by-step because the nature of subjects studied, for example microbiology, anatomy, and embryology, requires a process of incremental phases that reflect the sequential aspect. However, KSU students tend to be more global than KSAU-HS, and IMSIU with significant difference $(p=0.012)$. Similarly, a study conducted in 2014 to identify the differences between learning styles in Indian versus Malaysian medical schools showed no difference 
between the students.(27) However, the study includes only two categories, for example, sensing and global without including balanced learners. In this study, the learning styles of junior medical students were comparable to those of the seniors. The lack of distinctiveness between the two groups indicates that if medical students failed to adapt or improve their learning styles, they would likely develop a static form of learning throughout college.

In this data, gender was not associated with the learning styles of medical students, except in the visual/verbal category. Though both have low verbal preference, it was slightly higher in females than in males. Females are more likely to learn from listening, writing, and reading than males. A study that uses the ILS instrument showed that there is a gender difference in learning, where females are more sequential than males.(15) A study carried out in Saudi Arabia, which adopts the VARK questionnaire, showed that gender affects learning preferences among medical students $(P=0.019)$. (28) Another study targeting physiology students revealed that there is a gender gap in learning .(29) In contrast, a study on first-year medical students concluded that there is no gender difference. (30) In the present study, GPA was not associated with the learning styles. The results correspond with the findings of other studies that reported a similar conclusion. $(30,31)$

The study highlights the importance of learning preferences among medical students. Educators are advised to incorporate discussions and hands-on activities into the classroom, and students should be given enough time to grasp new information. Through visual illustrations, step-by-step learning could be highly beneficial. Educators should also evaluate their teaching methods to determine whether the instructional materials complement students' learning preferences. For example, some educators tend to give lectures in a disjointed manner, where they jump from one point to another, then return to the previous point. In this class, students with sequential learning style, most of whom are medical students, may find it difficult to keep up with the progress of the lesson.

Despite the pedagogical benefits of the study, it has some limitations. The cross-sectional design was one of the drawbacks that proved inadequate to determine a causal relationship. Further, the sample was considerably small and only examined the pre-clinical years. It is recommended to opt for longitudinal studies on a larger sample, including clinical-year students, which will provide more reliable data on the learning preferences among medical students in Saudi Arabia.

\section{Conclusion:}

The study showed that age and GPA had no association with students' learning styles, while gender was significantly correlated with the visual/verbal dimension. Most of the participants can learn alone, and/or in groups, and prefer visual illustrations supported by hands-on teaching in a stepwise process. It has also been shown that students in a single university tend to develop the same learning styles as they advance through the years.

\section{Abbreviations}

KSAUHS

King Saud bin Abdulaziz University for Health Sciences.

KSU

King Saud University.

IMSIU

Imam Mohammad Ibn Saud Islamic University.

VARK

Visual, Aural, Read/Write, and Kinesthetic.

K-LSI

Kolb's learning style inventory.

ELT

experiential learning theory.

ILS

Index of Learning Styles.

\section{Declarations}

\section{Ethical approval and consent to participate:}

Prior to data collection, an IRB approval was obtained from King Abdullah International Medical Research Center in Riyadh city. Informed consent was secured before participants enrollment in the study. The identity of the participants shall be kept anonymous and confidential.

\section{Consent for publication:}

Not applicable

\section{Availability of data and material:}

The datasets used and/or analysed during the current study are available from the corresponding author on reasonable request.

\section{Competing interest:}




\section{Funding:}

No funding was required.

\section{Authors' contributions:}

- AF: contributes effectively in data collection from KSAUHS and writing and Coordinate between the authors

- OF: contributes effectively in data collection from KSU and writing:

- RE: contributes effectively in data collection from KSAUHS and writing

- AT: contributes effectively in data collection from IMSIU and writing

- KS: contributes effectively in data collection from IMSIU and writing

- AO: contributes effectively in data analysis

- SA: provides supervision, revision, and guidance of the project.

- MM: provides supervision and participate in the conception of the project.

All authors read and approved the final manuscript.

\section{acknowledgement:}

The completion of our great project could not have been possible without the participation and assistance of these people, and we gratefully acknowledge their contributions. We would like to express our deep appreciation for the following: Ms. Maysoon Mohsin AlTameem for her contribution with data collection and the office of research at KSAU-HS for their continuous guidance.

\section{References}

1. Kieran Walsh ED. Oxford textbook of medical education (Book, 2013) [WorldCat.org] [Internet]. 2013 [cited 2020 Apr 10]. Available from: https://www.worldcat.org/title/oxford-textbook-of-medical-education/oclc/865162264.

2. Styles L, Coffield F, Moseley D, Hall E, Ecclestone K. Learning styles and pedagogy in post-16 learning A systematic and critical review This report critically reviews the literature on learning styles and examines in detail 13 of the most influential models. The report concludes that it matters fundamentall. 2004; (May 2014).

3. Panambur S, Nambiar V, Heming T. Learning style preferences of preclinical medical students in Oman. Oman Med J. 2014;29(6):461-3.

4. Lynch TG, Woelfl NN, Steele DJ, Hanssen CS. Learning style influences student examination performance. Am J Surg. 1998 Jul;176(1):62-6.

5. 10.1002/j.2334-4822.1992.tb00213.x

Fleming ND, Mills C. Not Another Inventory, Rather a Catalyst for Reflection. To Improv Acad [Internet]. 1992 Jun 1 [cited 2020 Apr 10];11(1):137-55. Available from: http://doi.wiley.com/10.1002/j.2334-4822.1992.tb00213.x.

6. Kolb AY, Kolb DA. The Kolb Learning Style Inventory - Version 4.0. Exp Based Learn Syst Inc. 2013;234.

7. Richard M, Felder, Barbara A, Soloman. Index of Learning Styles Questionnaire [Internet]. [cited 2020 Apr 10]. Available from: https://www.webtools.ncsu.edu/learningstyles/.

8. Felder RMSJ. Applications, reliability and validity of the index of learning styles. Int J Eng Educ. 2005;21(1):103-12.

9. Litzinger TA, Lee SH, Wise JC, Felder RM. A psychometric study of the index of learning styles@. In: Journal of Engineering Education. Wiley-Blackwell Publishing Ltd; 2007. p. 309-19.

10. Livesay G, Dee K, Felder R, Hites L, Nauman EOE. Statistical evaluation of the index of learning styles, session 2430 . In: Proceedings of the 2002 ASEE annual conference and exposition, 2002 June 16-19, Montreal, Quebec, Canada. In.

11. Hosford CC, Siders WA. Felder-soloman's index of learning styles: Internal consistency, temporal stability, and factor structure. Teach Learn Med [Internet]. 2010 Oct [cited 2020 Apr 10];22(4):298-303. Available from: http://www.ncbi.nIm.nih.gov/pubmed/20936578.

12. Cook DA. Reliability and validity of scores from the index of learning styles. Acad Med. 2005;80(10 SUPPL.).

13. Cook DA, Smith AJ. Validity of index of learning styles scores: Multitrait-multimethod comparison with three cognitive/learning style instruments. Med Educ. 2006 Sep;40(9):900-7.

14. Dumbauld J, Black M, Depp CA, Daly R, Curran MA, Winegarden B, et al. Association of Learning Styles with Research Self-Efficacy: Study of Short-Term Research Training Program for Medical Students. Clin Transl Sci. 2014 Dec;7(6)(1):489-92.

15. Hernández-Torrano D, Ali S, Chan CK. First year medical students' learning style preferences and their correlation with performance in different subjects within the medical course. BMC Med Educ. 2017 Aug 8;17(1).

16. D'cruz SM, Rajaratnam N. M C. Learning styles of first year medical students studying physiology in Tamil Nadu. Int J Med Res Heal Sci. $2013 ; 2(3): 321$. 
17. Buali WH, Al, Balaha MH, Muhaidab NS, Al. Assessment of learning style in a sample of saudi medical students. Acta Inform Med [Internet]. 2013 [cited 2020 Apr 5];21(2):83-8. Available from: http://www.ncbi.nlm.nih.gov/pubmed/24058248.

18. Abdallah R, Al-zalabani A, Alqabshawi A. R. Preferred learning styles among prospective research methodology course students at Taibah University, Saudi Arabia. J Egypt Public Health Assoc [Internet]. 2013 Apr [cited 2020 Apr 5];88(1):3-7. Available from: http://www.ncbi.nlm.nih.gov/pubmed/23528525.

19. Almigbal TH. Relationship between the learning style preferences of medical students and academic achievement. Saudi Med J. 2015;36(3):349-55.

20. Alghasham AA. Effect of students' learning styles on classroom performance in problem-based learning. Med Teach [Internet]. 2012 Apr [cited 2020 Apr 5];34 Suppl 1(SUPPL. 1):S14-9. Available from: http://www.ncbi.nlm.nih.gov/pubmed/22409185.

21. Nuzhat A, Salem RO, Hamdan N, Al, Ashour N. Gender differences in learning styles and academic performance of medical students in Saudi Arabia. Med Teach. 2013;35(SUPPL. 1).

22. Guraya SS, Guraya SY, Habib FA, Khoshhal KI. Learning styles of medical students at taibah university: Trends and implications. J Res Med Sci. 2014;19(12):1155-62.

23. Duff A, Duffy T. Psychometric properties of Honey \& Mumford's Learning Styles Questionnaire (LSQ). Pers Individ Dif. 2002 Jul 5;33(1):147-63.

24. Quinn MM, Smith T, Kalmar EL, Burgoon JM. What type of learner are your students? Preferred learning styles of undergraduate gross anatomy students according to the index of learning styles questionnaire. Anat Sci Educ [Internet]. 2018 Jul 1 [cited 2020 Apr 5];11(4):358-65. Available from: http://www.ncbi.nlm.nih.gov/pubmed/29096042.

25. Neel JA, Grindem CB. Learning-style profiles of 150 veterinary medical students. J Vet Med Educ [Internet]. 2010 Jan 1 [cited 2020 Apr 5];37(4):347-52. Available from: http://www.ncbi.nlm.nih.gov/pubmed/21135401.

26. Parmar AS, Balsara PH, Jaywant SS. Difference between Learning Style Preferences among Second Year MBBS and Second Year Engineering Students from Metropolitan City. 2020;1-7.

27. Heethal JP, Sahana GN, Ghosh S, Chitra G. Learning Style Preferences: A Comparison between Students of an. Indian a Malaysian Medical School. 2014;8(2):14-9.

28. Nuzhat A, Salem RO, Al Hamdan N, Ashour N. Gender differences in learning styles and academic performance of medical students in Saudi Arabia. Med Teach [Internet]. 2013 [cited 2020 Apr 5];35 Suppl 1(SUPPL. 1):S78-82. Available from: http://www.ncbi.nlm.nih.gov/pubmed/23581901.

29. Wehrwein EA, Lujan HL, DiCarlo SE. Gender differences in learning style preferences among undergraduate physiology students. Am J Physiol - Adv Physiol Educ. 2007;31(2):153-7.

30. 10.1152/advan.00043.2006

Baykan Z, Naçar M. Learning styles of first-year medical students attending Erciyes University in Kayseri, Turkey. Adv Physiol Educ [Internet]. 2007 Jun [cited 2020 Apr 10];31(2):158-60. Available from: https://www.physiology.org/doi/10.1152/advan.00043.2006.

31. Alharbi HA, Almutairi AF, Alhelih EM, Alshehry AS. The Learning Preferences among Nursing Students in the King Saud University in Saudi Arabia: A CrossSectional Survey. Nurs Res Pract. 2017;2017:1-7.

\section{Figures}



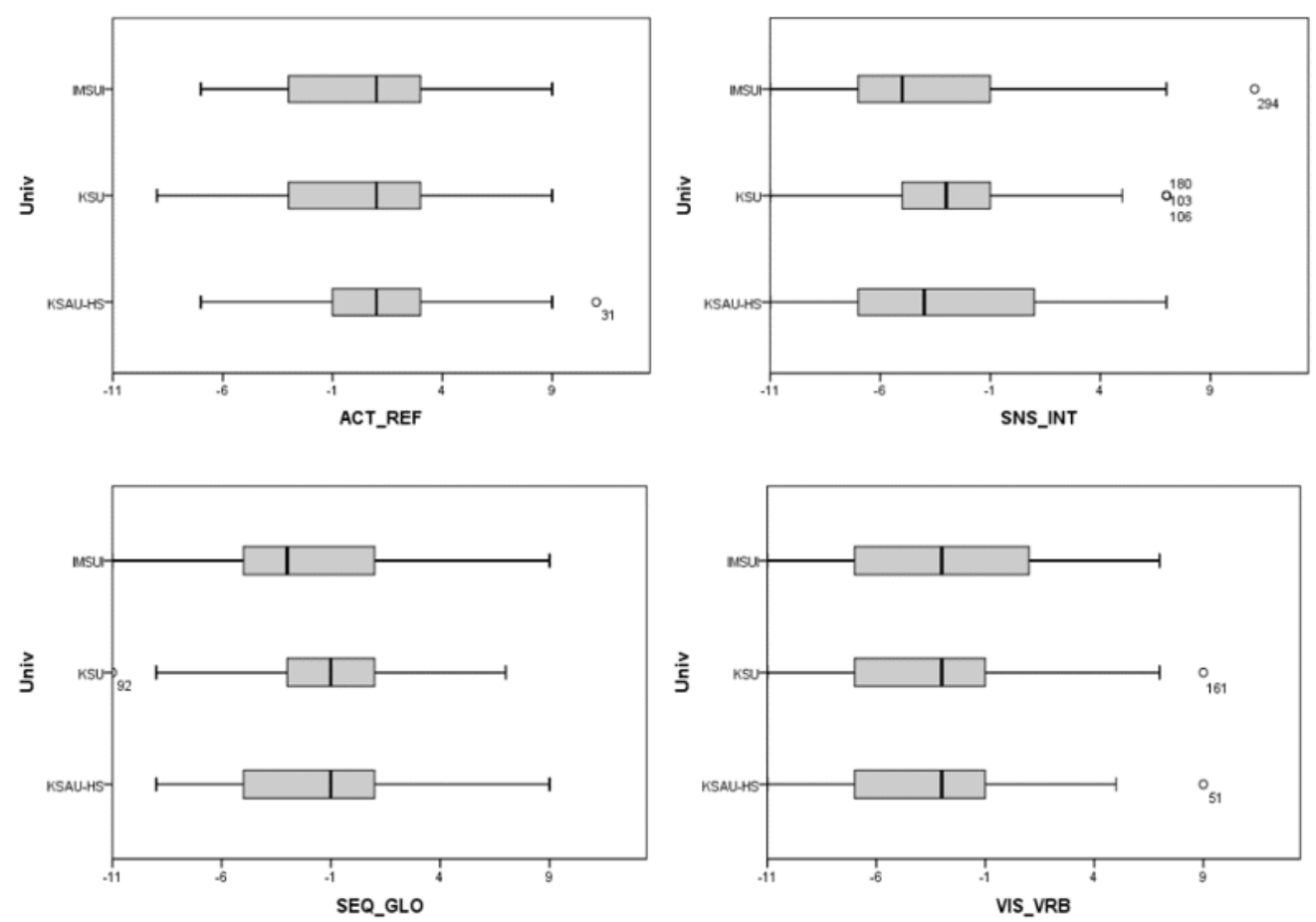

KSAUHS: King Saud bin Abdulaziz University for Health Sciences. KSU: King Saud University. IMSIU: Imam Mohammad ibn Saud Islamic University. ACT: active. REF: reflective. SNS: sensing. INT: intuitive. SEQ: sequential. GLO: global. VIS: visual. VRB: verbal. The score range is from +11 to -11 .

\section{Figure 1}

Graph 1: Box whisker plot of participants' learning styles according to participants' university 